\title{
The Status of Carex elongata (Cyperaceae) in Yorkshire
}

\author{
Alastair Fitter ${ }^{1}$, Martin Hammond ${ }^{2}$, Meg Huby ${ }^{3}$, Kevin Walker ${ }^{4}$, Philip Whelpdale ${ }^{5}$ \\ 1,3York, UK; ${ }^{2}$ Middlesborough, UK; ${ }^{4}$ BSBI, Harrogate, UK; ${ }^{5}$ Yorkshire Wildlife Trust, \\ York, UK
}

*Corresponding author: A.H. Fitter: ahf1@york.ac.uk

This pdf constitutes the Version of Record published on 30 th December 2021

\begin{abstract}
Gingerbread or Elongated Sedge Carex elongata L. is a rare plant in eastern England and the Yorkshire populations are isolated from the main distribution. It has only ever naturally occurred at five sites and is extant at two of them, one of which probably results from a recent colonisation event. It has been re-introduced near another of its historic sites. At its principal site, Askham Bog near York, the plant has expanded its population considerably over the last 40 years. Its local distribution appears to be strictly limited by topography and winter flooding. Its ability to colonise new sites and to expand populations show that earlier concern about seed viability was misplaced.
\end{abstract}

Keywords: historical distribution; Askham Bog; alder; establishment

\section{Introduction}

Carex elongata is a scarce plant in Britain (David, 1994), recorded from 66 tetrads in the period 2000-2019, and has Near Threatened status (Cheffings and Farrell, 2005). It has a disjunct distribution in Britain: it occurs in the south-east and in the west from south Wales to central Scotland. It is also well distributed in the northern part of Ireland. In the east of Britain, north of Suffolk, the only records are from Yorkshire (Fig. 1). This predominantly western distribution is surprising, since the global distribution is centred on central rather than western Europe.

\section{Historical Records}

Before 1900

The Yorkshire populations have a well-documented history. In the mid-19th century, C. elongata was known from three localities in v.c.61 (Langwith Common) and v.c.63 (Aldwarke and Doncaster) (Table 1 ; Fig. 2), but by the late $19^{\text {th }}$ century was apparently extinct at all of these: Lees (1888) stated that it "is probably extinct in its only Yorkshire station near Sheffield". The record from Aldwarke, near Rotherham and therefore quite near Sheffield, was the first record of the plant for the British and Irish flora. The record from Doncaster may refer to the same population that was reported at Fishlake in 1945; whether it survived unrecorded between 1847 and 1945 is unclear.

There are two reports from v.c.65, one by Slater (1884) from Aldwark near Boroughbridge (SE36) and one from Langwith (SE28); these are errors probably 
based on the similarity of the place names to the existing records. The Aldwark error appears first to have been made by Baines (1840) in his early Flora of Yorkshire. The Langwith record is variously attributed to S. Thompson, T. Kirk and (after his death) J.G. Baker, but is apparently a mistake for Langwith Common (SE64). There is no evidence that $C$. elongata has ever occurred in v.c.65.

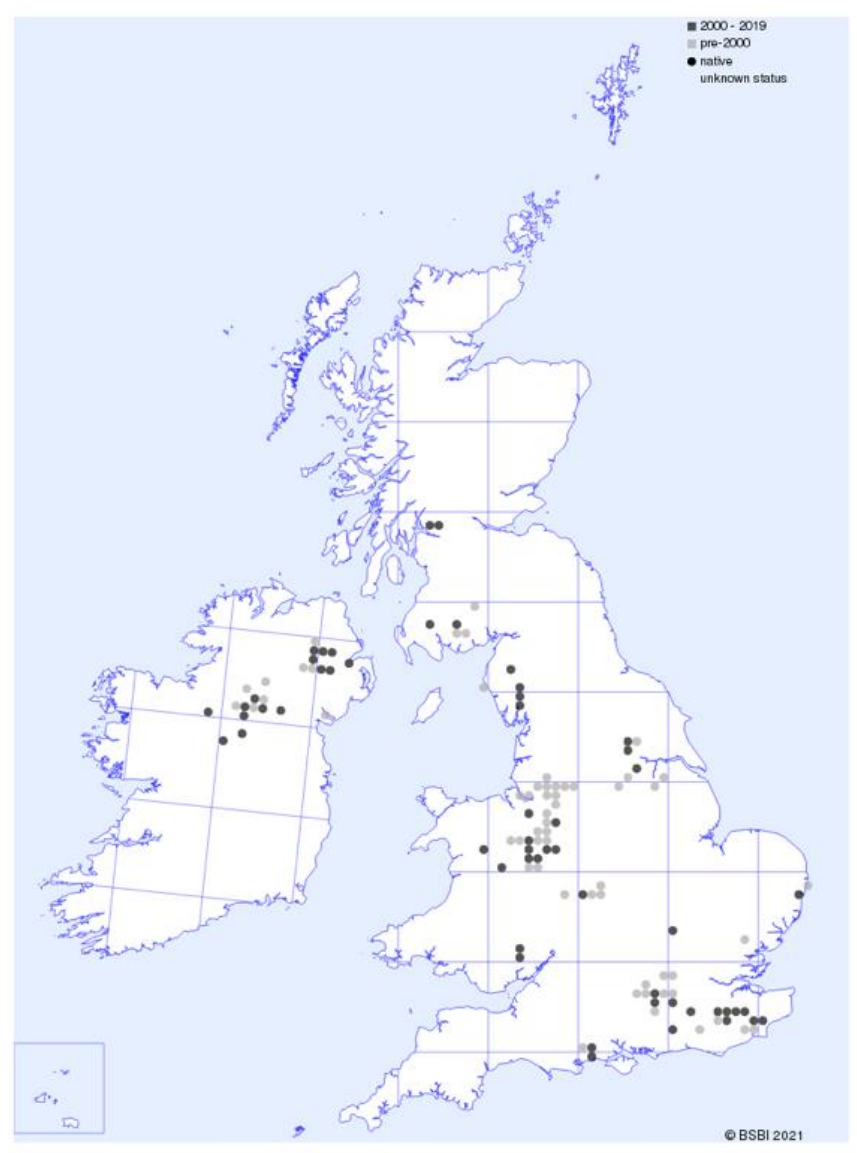

Figure 1. Distribution of Carex elongata in the UK (based on the BSBI Distribution Database: https://database.bsbi.org/

Table 1. Summary of all confirmed records of Carex elongata in Yorkshire

\begin{tabular}{|l|l|l|l|l|}
\hline VC & Locality & $\begin{array}{l}\text { Grid } \\
\text { ref }\end{array}$ & Date & $\begin{array}{l}\text { First Named } \\
\text { Recorder }\end{array}$ \\
\hline $61^{1}$ & Langwith Common, nr York & SE64 & $1856-1874$ & J Carroll (1874) \\
\hline 62 & None & & & \\
\hline 63 & Doncaster & SE50 & 1847 & J Hardy \\
& Fishlake, nr Doncaster & SE61 & $1945-1966^{2}$ & JM Taylor \\
& Aldwarke, nr Rotherham & SK49 & $1803-1876^{3}$ & J Salt \\
\hline 64 & Askham Bog, nr York & SE54 & $1892-$ now & BB LeTall \\
& Bishop Wood, nr Selby & SE53 & $2007-n o w$ & M Hammond \\
\hline 65 & None & & & \\
\hline
\end{tabular}

${ }^{1} \mathrm{~A}$ record in TA31 attributed to P Cook and FE Crackles is an error. ${ }^{2}$ The plant has been re-introduced nearby.

${ }^{3}$ An undated, unattributed and unlocalised record exists for Sheffield SK38. 


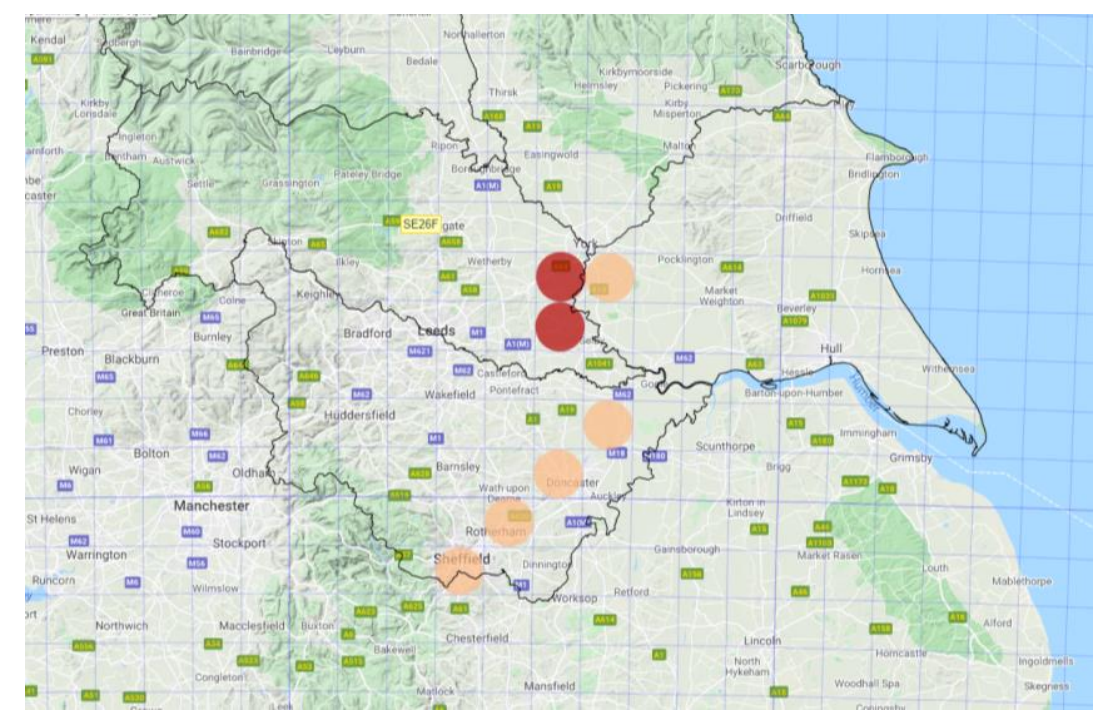

Figure 2. Locations of sites where Carex elongata has been recorded in Yorkshire. Extant records are shown red. The records for Sheffield (SK38) and Doncaster (SE50) are unlocalised and may refer to those for Aldwarke (SK49) and Fishlake (SE61) respectively

\section{Since 1900}

Since 1900, the only confirmed sites have been at Fishlake (VC 63), where it was recorded between 1945 and 1966 (it has been reintroduced nearby), and in two places in the Vale of York, both in VC 64. Currently the largest population in Yorkshire is at Askham Bog, where it has increased greatly in abundance over the last 40 years. The history of the species at Askham Bog suggests a new colonisation event occurred in the late $19^{\text {th }}$ century (Fitter \& Smith, 1979). In Fitter \& Smith (1979) it was suggested that the first record at the site was in a Yorkshire Naturalists' Union circular for 1900 attributed to J.H. Wilkinson, but it is now known that the first record was by B.B. LeTall, a teacher at Bootham School in York, in 1892 (Sledge, 1946). Although Lees visited Askham Bog regularly there is no evidence that he was aware of its occurrence, and it was not listed in either his Flora of West Yorkshire (Lees, 1888) or the detailed account of the flora of the site by Le Tall himself published in 1879 (Le Tall, 1879). It therefore appears to have become established between 1879 and 1892 .

The first physical evidence of the presence of $C$. elongata at Askham Bog is a herbarium specimen in the Yorkshire Museum, collected by C. M. Rob in 1936, and two specimens in the British Museum, collected by W.A. Sledge in the same year. There is no further record until 1958 (A. Wegener, another teacher at Bootham School, who made detailed records at the site), though its presence was presumably well known. The record appears in the first national plant atlas (Perring \& Walters, 1962 ) and thereafter the species was recorded at Askham Bog frequently by various Yorkshire and visiting botanists, starting with R.W. David in 1977, although it was also seen by A. Fitter from 1973 onwards and was recognised as an important element of the flora of the site in management plans produced by the Yorkshire Naturalists' Trust (now Yorkshire Wildlife Trust) who own and manage the site. 
For 40 years after 1966, when the plant was last recorded at Fishlake, the Askham Bog population was the only one known in Yorkshire. In 2007 the plant was discovered by M. Hammond at Bishop Wood (SE5533), $18 \mathrm{~km}$ south of York and 16 $\mathrm{km}$ from Askham Bog; that population persists. Recently, plants propagated from seed from the Bishop Wood population have been reintroduced on a farm pond near to the original Fishlake site (J. Scott, pers. comm.).

\section{Extant populations}

\section{Askham Bog}

The Askham Bog population is now probably the largest in Britain, as detailed below. The plants occur in a well-defined area, originally only under alder Alnus glutinosa, in an area that conforms to National Vegetation Classification (NVC) category W6 woodland (Rodwell, 1991). In recent years, the plants have spread into areas of oak-hazel and birch woodland. Some of the tussocks at Askham Bog are large but there is a wide size range, consistent with this being a well-established and expanding population.

In 1977-78, J. Frost surveyed the population at Askham Bog as part of a B.Sc. dissertation (Frost, 1978). She mapped 250 plants that were principally localised in a small area within a narrow topographic band. The entire colony covered an area of around $100 \times 50 \mathrm{~m}$, with a small outlying group. In recent years it was apparent that the population had expanded considerably. In February and March 2019 M. Huby and $A$. Fitter resurveyed the population, using the same $50 \mathrm{~m}$ grid used in 1978. GPS readings revealed that there were inaccuracies in this grid, but for comparison with the earlier survey, the grid was retained. However, the maps have been corrected using the GPS readings so that the locations of plants are shown more accurately.

For the survey, the $50 \times 50 \mathrm{~m}$ grid squares were subdivided into $10 \times 10 \mathrm{~m}$ cells using tapes and canes, and the numbers of plants counted in each cell independently by each surveyor. When counts agreed to within a small margin of error, the mean of the two counts was recorded; where the disagreement was greater, the cell was re-counted. The area surveyed was west of the cross-dyke that separates Middle Wood from Far Wood. A small number of plants were also noted adjacent to this dyke in a section where the posts marking the $50 \times 50 \mathrm{~m}$ grid are no longer present; the locations of these plants were recorded in March 2021 by A. Fitter using a GPS app on an iPhone. Recently a single but well-established plant was discovered $100 \mathrm{~m}$ east of the existing population in the centre of Middle Wood.

The counts in 2019 and 2021 reveal that the population at Askham Bog has increased from 250 to over 6000 plants since 1978, i.e. in just over 40 years (Fig. 3). For a species listed as Near Threatened in Britain, this is a reassuring finding. The survey also revealed, as was apparent on the ground, that the population has spread both in towards the centre of the Bog, where the peat dome is slightly raised and the peat is more acid and, in summer, drier; and also to the south and east. There has been no spread, however, westwards, even though there was an outlier population there in 1978.

This pattern of spread is surprising. The woodland to the west is alderdominated (W6) and apparently very similar to the area in which $C$. elongata was first established. Alder woodland is regarded as typical habitat for the species, especially in its core distribution area in northern Europe where it is a characteristic species of the phytosociological unit known as Caricetum elongatae - Alnetum 
glutinosae (Prieditis, 1997). In contrast the areas into which C. elongata has spread include a rather dry oak-hazel woodland (NVC W10), acid birch woodland with much Molinia (NVC W4), and a species-rich, birch-dominated fen woodland (NVC W2).

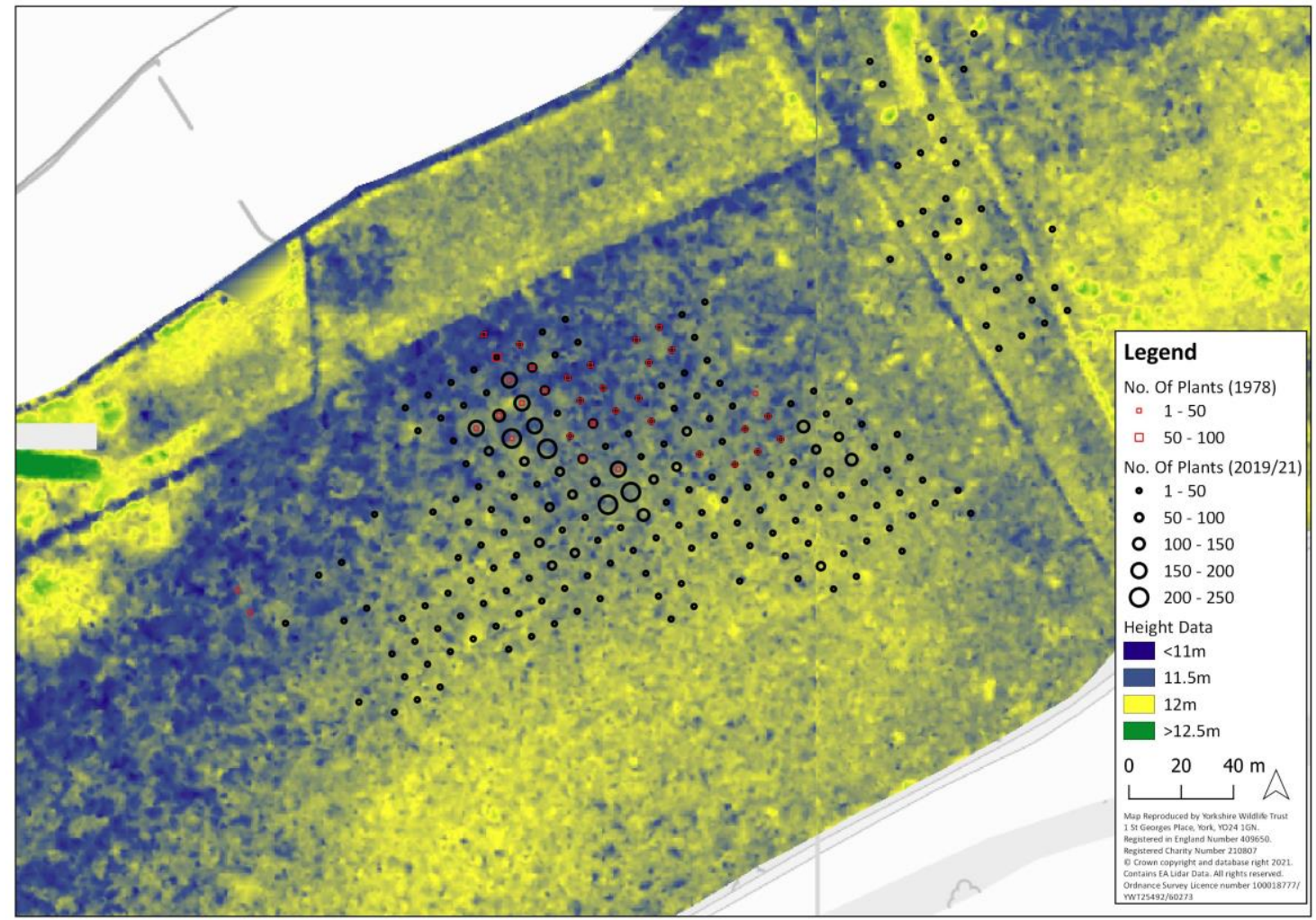

Figure 3. Distribution of Carex elongata at Askham Bog in 1978 (red symbols) and in 2019-2021 (black symbols); size of symbols is proportional to the number of plants in square of the $10 \times 10 \mathrm{~m}$ sampling grid.

The current distribution fits between the 11.50 and $11.80 \mathrm{~m}$ AOD contours (Fig. 3 ), determined from LIDAR. The lower limit is easily confirmed on the ground: in February 2021, when the surface water level was at about $11.50 \mathrm{~m}$, almost no $C$. elongata plants were in the flooded areas, whereas $C$. elata tussocks were abundant there. The upper level may be determined by $\mathrm{pH}$, which is below 4 above $11.80 \mathrm{~m}$, or by drought, since the higher peat levels are dry in summer. In August 2020, numerous plants growing at these high topographic levels in W4 woodland were shrivelled and clearly affected by drought.

\section{Bishop Wood}

The population at Bishop Wood was first discovered by M. Hammond in 2009. In March 2021 the population comprised 48 plants, mainly small and in an area about 5 $\mathrm{m}$ across on the edge of a small pond, with a further 5 plants about $5 \mathrm{~m}$ distant on the same edge and 3 about $5 \mathrm{~m}$ in the opposite direction next to a much smaller and certainly seasonal pond. The total so far discovered is therefore approximately 56 plants, but the wood is large $\left(3.5 \mathrm{~km}^{2}\right)$ and other colonies may remain to be discovered. The areas of the wood where $C$. elongata has been found are on clay soils dominated by ash Fraxinus excelsior with planted poplar Populus $x$ canadensis, 
and therefore very different from Askham Bog, although it shares some unusual elements of ground flora, including Calamagrostis canescens and Lysimachia vulgaris.

The recent discovery and small size of the plants compared to those at Askham Bog suggest a recent colonisation event. It is striking that both Askham Bog and Bishop Wood are directly adjacent to the main east coast railway line, but it is hard to conceive a dispersal mechanism for a sedge that relies on railway transport, although it is perhaps worth noting that the section of the line that passes through Bishop Wood was constructed in the early 1980s.

\section{Ecological Implications}

Over the last 200 years, C. elongata has been reliably recorded from five sites in Yorkshire and is now present in two, although re-introduced in a third. One of those sites, Askham Bog, sustains what is probably the largest population in the UK, even though the site is something of an outlier from the main area of distribution. There is no evidence that Carex elongata has ever occurred in v.c.62 or v.c. 65.

Both the former and the current distribution of the plant at Askham Bog provide evidence that hydrology is important. Frost (1978; quoted by Fitter \& Smith, 1979) suggested a topographic range as small as $10 \mathrm{~cm}$; the more recent survey suggests that a range of $30 \mathrm{~cm}(11.50-11.80 \mathrm{~m} \mathrm{AOD})$ is more likely.

At Askham Bog, the plant has increased 24 -fold in just over 40 years and its growth form means that this reproduction must have been from seed. Earlier one of us (A. Fitter) stated that "Surprisingly the seeds seem almost completely inviable, as all attempts at germinating them have failed" (Fitter \& Smith, 1979). This statement was based on inadequate evidence and is demonstrably wrong, given the substantial expansion of the population, although it has been repeated by David $(1978,1994)$ and by Stroh \& Spencer-Vellacott (2015). There is good evidence that seed from other populations is viable and will germinate under the right conditions in later papers (e.g. Schutz \& Rave, 2003; Hulik and Douda, 2017).

David (1994) suggested that $C$. elongata is "often epiphytic on fallen boughs that raise it above flood level" and that "ancient wooden camp-sheathing [by canals] provides the kind of pedestal that it enjoys". This may be a misinterpretation. Plants are found growing on fallen logs and stumps at Askham Bog, but they make up a small proportion of the total. Mallabar (1998) in a survey of nearly all the UK populations, stated that "[in] The sites sampled... all regeneration being epiphytic upon living or decaying wood", but it is hard to see how this could be the case given that "many mature specimens were found growing directly on the peat substrate". Regeneration on fallen wood is not unique to $C$. elongata; $C$. remota shows this behaviour at Bishop Wood.

An alternative explanation would be that the seeds are dispersed by floating when the site floods: when water levels subside, some seeds then land on stumps and logs and germinate there. This hypothesis would also explain why the plants have colonised eastwards but not westwards at Askham Bog, since at times of flood there is water flow from west to east at the site. It would also explain why the plants are not found below the $11.50 \mathrm{~m}$ contour, since such areas are wet through much of the winter, possibly restricting opportunities for germination. It seems very unlikely that its regeneration requirements are as constrained as suggested by earlier authors. 
Despite having become extinct in three of its five known Yorkshire stations, $C$. elongata is expanding its population at Askham Bog and has recently colonised a new site in the Vale of York. Its status therefore seems to be secure if these sites remain well protected, and they have a particularly high importance in the overall conservation of the species in the UK.

\section{Acknowledgments}

We are indebted to the survey work undertaken by J. Frost as part of her B.Sc. degree at the University of York in 1978; despite attempts to make contact through the University of York alumnae network, we have been unable to invite her to be an author of this paper which would otherwise have been appropriate.

\section{References}

Baines. H. 1840. The Flora of Yorkshire. London: Longman, Orme, Brown, Green \& Longman.

Cheffings, C.M. \& Farrell, L. 2005. The Vascular Plant Red Data List for Great Britain. Species Status No. 7. Peterborough: Joint Nature Conservation Committee.

David, R.W. 1978. The distribution of Carex elongata L. in the British Isles. Watsonia 12: 158-159.

David, R.W. 1994. Carex elongata (L.) In: Stewart, A., Pearman, D.A., \& Preston, C.D. (eds.) Scarce plants in Britain. pp. 82-83. Peterborough: Joint Nature Conservation Committee (JNCC).

Fitter, A.H. \& Smith, C.J. 1979. A Wood in Ascam. Askham Bog 1879-1979. York: Ebor Press and Yorkshire Naturalists' Trust.

Frost, J. 1978. The Ecology and Distribution of Carex elongata at Askham Bog. B.Sc. Dissertation. University of York.

Hulik, J. \& Douda, J. 2017. Germination strategies of two dominant Carex species in a swamp alder forest: implications for restoration. Biologia 72: 370-377.

Lees, F.A. 1888. Flora of West Yorkshire. London: Lovell, Reeve \& Co.

Le Tall, B.B. 1879. The plants of Askham Bog. Reprinted from The Natural History Journal, The Societies in Friends' Schools.

Mallabar, J. 1998. Habitat status \& niche requirements of Carex elongata in Britain. M.Sc. thesis, University of Birmingham.

Perring, F.H. \& Walters, S.M., eds. 1962. Atlas of the British Flora. London: Thomas Nelson \& Sons.

Prieditis, N. 1997. Alnus glutinosa - dominated wetland forests of the Baltic Region: Community structure, syntaxonomy and conservation. Plant Ecology 129: 4994.

Rodwell, J.S. 2001. British Plant Communities. Volume 1. Cambridge: Cambridge University Press.

Schütz, W. \& Rave, G. 2003. Variation in seed dormancy of the wetland sedge, Carex elongata, between populations and individuals in two consecutive years. Seed Science Research 13: 315-322.

Slater, H.H. 1884. The flora of Ripon and neighbourhood. Transactions of the Yorkshire Naturalists' Union 1882, Series E: Botany: 125-184.

Sledge, W.A. 1946. Askham Bog. The Naturalist no. 819, p.50. 
Stroh, P. \& Spencer-Vellacott, P. 2015. Carex elongata L. Elongated Sedge. Species Account. Botanical Society of Britain and Ireland. Available at: https://bsbi.org/wp-content/uploads/dlm uploads/Carex elongata species account-1.pdf

Copyright retained by author(s). Published by BSBI under the terms of the Creative Commons Attribution 4.0 International Public License.

ISSN: $2632-4970$

https://doi.org/10.33928/bib.2021.03.482 